\title{
Review of Rudi Verburg's Greed, Self-Interest and the Shap- ing of Economics. San Francisco, CA: Routledge, 2018, 216 pp.
}

\author{
A. M. C. WATERMAN \\ St. John's College, University of Manitoba
}

Rudi Verburg "tells the story of the rise and shaping of economics as a tale of the evolving relationship between greed and self-interest" (4-5). There is much in his story that is both interesting and true. But in my opinion, he has greatly exaggerated the importance of 'greed', and has failed to perceive the shape of modern economics and its evolution.

\section{VERBURG's STORY}

Greed, Self-Interest and the Shaping of Economics contains eight chapters, the first of which is introductory, and the last of which is a summary and a conclusion. In-between come (ii) "The rise of greed in early economic thought: from deadly sin to social benefit"; (iii) "The Mandevillean triangle”; (iv) “Adam Smith's struggle with Rousseau's critique of commercial society"; (v) "Self-interest after Smith: from passion to behavioural assumption"; (vi) "The wheels of 'greed, and the war amongst the greedy"; and (vii) "The neoclassical turn and the fading-out of greed and pride".

Verburg gets a lot of the history right. He is right about the Jansenists-Nicole and Domat-and the pioneering work of Boisguilbert (24-33); he correctly reports Mandeville's important contribution and the adoption of its analytical insights by Hume, Smith and others (45-50); he is correct to identify a drastic shift in economic thinking produced by Malthus' first Essay (105-123) and the stimulus this produced for radical reform in Britain (117-123); he correctly reports the English Romantics' revulsion from Radical-Whig reform, and from the political economy that informed it (130-136); and his account of Engels and Marx is at least as good as that of most textbooks (151-165). Verburg makes extensive and intelligent use of a wide range of the secondary literature, including some of my own work on Malthus; and his discussion of many aspects of eighteenth-century intellectual history is scholarly and interesting in itself.

Yet despite these many virtues, his book is ill-conceived and its message-insofar as it is clear-is wrong. 
Verburg's study "aims to answer two questions. [. . .] how did philosophers in the seventeenth and eighteenth centuries construct a narrative of a positive-sum world? [. . .] what happened to this narrative so that greed and vanity [. . .] disappeared from the theoretical framework of mainstream economics?" (3). The book appears to have been inspired by the financial crisis of 2008 which many blamed on "greed" (1-3). It is illconceived, in my opinion, because what counts as 'economics' is never made clear; because many of the philosophical doctrines reported are therefore irrelevant; and because Verburg often confounds the positive with the normative, which gives his narrative a somewhat polemical tone. It is wrong because 'greed' has little or nothing to do with 'the shaping of economics'.

'Economics' is never defined in this book, and therefore "mainstream economics" (3) as distinct from any other 'economics' is left vague and uncertain. The term appears to designate discourse about production and trade, and though scarcity is occasionally mentioned there is no recognition that 'economics' is about 'economising', and that 'economising' is about scarcity. Verburg therefore fails to see that 'economics' is not a body of doctrine about how production and trade ought to be ordered, but a method of thought about how production and trade actually do take place; and how they arise from the attempts of individuals to cope with scarcity. We now call this method of thought 'economic analysis' and can trace an unbroken continuity of analytical development from Boisguilbert: through Cantillon and Hume, Quesnay, Adam Smith and his successors in the 'English School', including Marx (Waterman 2008; Hollander 2008), to the latest Nobel Prize winners. Many economists and historians of economic thought, therefore, might quarrel with Verburg for taking Marshall (1890) as his terminus ad quem. He was indeed modern-and defined the 'mainstream' at that time-by comparison with Malthus in 1815; as Malthus was in 1815 by comparison with Boisguilbert in 1696. But we are now a century on from Marshall and his Principles. Notwithstanding Boisguilbert's claims, Roger Backhouse (2017) in his new biography simply calls Paul Samuelson the 'Founder of Modern Economics'and knows that few, if any, will disagree with him.

Verburg seems obsessed by 'greed', which is not a positive term in social-scientific discourse but a normative one. It conflates two of the Seven Deadly Sins: Gluttony and Avarice. If we observe either in others we disapprove. If we recognise either in ourselves we are ashamed and repent. But it is not always possible to recognise them clearly in ourselves 
and others, for human motives are usually mixed. Suppose my income is in the top 2\%: yet I desire, and take lawful measures to procure, an extra $\$ 50,000$ per annum. Why? To enrich my grandchildren? To give more to the church or the symphony orchestra? To buy champagne and lay down vintage wines to impress my guests and/or to cater to my gluttony? To make a large donation to some new public building and get my name on the wall with the local plutocrats? To enjoy 'tyrannising over my bank balance' as Keynes put it? Some or all of these? My act is certainly rational and self-interested. But is it 'greed'? Who is to say? The most we can say is that what some would call 'greed' may be part of my mixture of motives.

What this means is that it is pointless to investigate the way in which 'greed' affects economic behaviour. We can't know and it doesn't matter. For self-interest is not "conditioned and disciplined greed" as Verburg tendentiously asserts (5). It is a survival mechanism implanted in us by natural selection that we humans share with all other sentient beings, without which we would not exist. Greed is simply a particular manifestation of self-interest that we disapprove of on moral or religious grounds. Self-love, which played an important part in Verburg's story for about five decades, is simply self-interest in theological disguise: as used by the Jansenists and Mandeville to discredit self-interest; and by Butler and Josiah Tucker-and Adam Smith-to rehabilitate it. The concept of 'self-interest' has everything to do with 'the shaping of economics': the concept of 'greed' very little. Much of Verburg's discussion of eighteenthcentury philosophy therefore, well-informed as most of it is, has little or no bearing on 'the shaping of economics'.

All would agree, however, that the most important single text in the shaping of what has become modern economics is Wealth of Nations. ${ }^{1}$ Smith was a 'philosopher'. What then of Smith's philosophical contemporaries, and of his long 'struggle with Rousseau's critique of a commercial society' (chapter 4)? There is no doubt that Smith did 'struggle' with Rousseau through six recensions of The Theory of Moral Sentiments, ${ }^{2}$ and Verburg's chapter 4 is a useful summary of this episode. But what has that to do with 'economics'? Like most other eighteenth-century 'philosophers', Smith wore more than one hat. In TMS he wore his moralist's hat.

\footnotetext{
${ }^{1}$ This and all subsequent references to the Wealth of Nations, abbreviated as ' $W N$ ', will be to the Oxford edition (Smith [1776] 1976). References include, in this order, book, chapter (in lower case Roman numerals), part (if applicable), and paragraph (in Arabic numerals).

${ }^{2}$ This and all subsequent references to The Theory of Moral Sentiments, abbreviated as ' $T M S$ ', will be to the Oxford edition (Smith [1759, 1790] 1976).
} 
In $W N$ he wore his political œconomist's hat. So do we need TMS in order to understand $W N$ ? It is fashionable to say so, especially among those historians and philosophers who now dominate Smith studies. But in my opinion this is to misunderstand $W N$, the central message of which is the social optimality of "the natural system of perfect liberty and justice" ( $W N$, IV.vii.c.44; my emphasis).

Economic analysis in $W N$ shows how 'perfect liberty' works if individuals are motivated by self-interest and their economic actions coordinated by markets: provided that "every man [. . .] does not violate the laws of justice"-where 'justice' means commutative justice ( $W N$, IV.ix.51). For unless most individuals obey the rules of the game even when the referee is not looking, the market game will quickly cease to be worth playing, and 'perfect liberty' will lead to anarchy. But they will only do so if just behaviour is habitual. Conscience is not innate, and just behaviour must be learned. TMS shows how this happens, and is therefore an integral part of Smith's complete social theory. It explains how a sense of commutative justice comes into being, and why this is a necessary condition of a wellfunctioning market economy. But we do not need it in order to understand the economics of $\mathrm{WN}$. Given only the assumption of a widespread sense of justice, $W N$ is a free-standing account of economic growth and development driven by the private motivation of individuals (Waterman 2015).

Verburg's often illuminating accounts of Rousseau and Hume are therefore redundant, as are subsequent accounts of Robert Owen, William Thompson, Veblen, and Tawney (chapters 6 and 7). They have nothing to tell us about economics. It is astonishing that the only major philosopher to have played a leading part in the shaping of modern economics, Joseph Butler, is completely ignored in this book.

\section{ECONOMICS AND GREED}

For a brief period, circa 1690-1730, greed did indeed have an important part to play in the shaping of economics.

Economics is a putatively scientific study of the way in which human societies cope with scarcity. It emerged in the early eighteenth century as a gradual mutation of Montchrétien's économie politique ([1615] 1889) as it came to be realised that the King's ministers could never have the information necessary to manage a large, complex modern economy like that of France or England (WN, IV.ix.51).

Jansenist theologians had perceived that many socially beneficial acts are the unintended consequence of 'cupidity'; and they understood this 
as an example of Augustinian theodicy, whereby God uses human sin as a remedy for sin. 'Cupidity', an inordinate desire for wealth, is a species of Greed, which itself conflates two of the seven deadly sins. Thus greed, in the second sense (Avarice), could be regarded as a motor of economic activity, and so a remedy not only for sin but also for scarcity, itself a consequence of primordial sin (Genesis 3: 1-18).

Pierre de Boisguilbert (1646-1714) had been a pupil of the Jansenists, and he generalised their pregnant insight. Abstracting from theology and ethics, he explained how general economic activity in France was an unintended consequence of private, self-regarding acts of individuals. It was impossible for the King to control the economy; and unnecessary to try, since competition maximized wealth at equilibrium. His Détail de la France ([1695] 1966) is now regarded as the origin of modern economics (Faccarello 1999).

Mandeville grasped Boisguilbert's key insight. But (along with Pride, another of the seven deadly sins) he gave [Greed=Avarice] centre stage in his notorious slogan 'Private Vices, Publick Benefits': a reductio ad absurdum of the Augustinian theodicy employed by the Jansenist moralists, whose doctrine he knew. Like the Jansenists, Mandeville seems genuinely to have regarded self-love as an 'evil passion' (Faccarello 1999, 27). The 'Publick Benefits' of market exchange are driven by this 'Private Vice'. But Mandeville's doctrine was reviled in England as blasphemous, and his book indicted by the Grand Jury of Middlesex as a public nuisance.

For Calvinist theology, which had fostered that Augustinian account of self-love assumed by Jansenists and Mandeville, was long dead in England. And even in Presbyterian Scotland, a remarkable affirmation of selfinterest in business appeared in the Shorter Catechism promulgated in 1647, the high-water mark of British Calvinism:

Q.74. What is required in the eighth commandment?

A. The eighth commandment requireth the lawful procuring and furthering the wealth and outward estates of ourselves and others.

The increase of one's own wealth is made a Christian duty. As Michael Lessnoff $(1994,63)$ has shown in detail, we have here "a profit-seeking ethic totally congruent with Weber's 'spirit of capitalism'”. As a child, Adam Smith could repeat the whole of the Shorter Catechism by heart (Kennedy 2013, 465). 
Those who sought to purge Mandeville's doctrine of its objectionable features whilst retaining its valuable account of a market economy driven by private interest, had therefore to differentiate self-love from 'vice'. The greatest to do so was Joseph Butler (1692-1752). His fifteen Rolls Sermons ([1726] 1969) were preached in the immediate aftermath of the public outcry aroused by the 1723 edition of the Fable. As against Shaftesbury's Characteristicks (1711), Butler ([1726] 1969) showed that the ends of private good and public good "do indeed perfectly coincide" (36); that "selflove is one chief security of our right behaviour towards society" (36); that under Providence much unintended social good is produced by self-regarding actions (37-38); and that "there is seldom any inconsistency between what is called our duty and what is called interest" (67). Sermons XI and XII, "On the Love of our Neighbour" (164-202), recognize that selflove is a duty commanded by Christ himself (Waterman 2014b).

David Hume's essay 'Of Luxury' ([1752] 1994) which was also a response to Mandeville, acknowledged him in the Introduction to his first work-along with Locke, Shaftesbury, Hutcheson, and Butler-as one of those "who have begun to put the science of man on a new footing" (Hume [1739-1740] 1888, xxi). Of these, Hume was indebted in particular to Butler: not only for the vindication of self-love but also-far more important for his philosophical project-for Butler's powerful demonstration of "the Ignorance of Man" (Sermon XV). For given the moral acceptability of selflove together with the limited power of the human mind to comprehend the working of Divine Providence, the way was open to build on Mandeville's foundations that theory of 'spontaneous order' in human society seen today as the characteristic contribution of the Scottish Enlightenment to social theory (for example, Hamowy 1987). The multifarious activities of any large human society, most notably its economic activities, arise and can only arise in a gradual, unplanned, accidental, piecemeal fashion in response to the incentives to a myriad individual, self-regarding actions created by others' needs and desires. Butler had established that this seemingly providential outcome might arise from a wholly virtuous attention by all individuals to their 'interest' as determined by the Christian duty of self-love.

Like Butler's chaplain and friend, Josiah Tucker ([1755] 1993, 58), whose writings he knew, Adam Smith made self-love "the governing principle in the intercourse of human society" ( $W N$, I.ii.2-3). Self-interest-often used synonymously with self-love-was used as a purely positive term 
without normative significance, and Greed became otiose as an explicans in economic discourse.

\section{THE SHAPING OF ECONOMICS}

Adam Smith began the 'shaping' of modern economics by distinguishing it clearly from the tradition of Political CEconomy from Montchrétien to Sir James Steuart (1712-1790), which rested on "the old idea of an entity called the state or the nation existing outside the individuals who constitute its subjects or members" (Levy and Peart 2013, 372). Individual motivation drives economic activity. Individual needs and preferences determine social welfare. "What is properly called Political CEconomy" Smith defined as "a branch of the science of a statesman or legislator", an "inquiry into the nature and causes of the wealth of nations" ( $W N$, IV.ix.38; IV.Intro; my emphasis): a heuristic enterprise that is in principle disinterested, open-ended and scientific. Every English author after Smith insisted that Political Economy was strictly a science, and unlike 'the foreign school' distinguished it sharply from 'the art of government'. Its business was to find out: not to advise or to recommend (Waterman 2008).

In keeping with the scientific claims of 'classical' Political Economy, Smith's Inquiry relied heavily on what we now call 'economic analysis' to elucidate the working of a modern, commercial economy. Pioneering work had been done by the French successors of Boisguilbert: Cantillon, Quesnay and Turgot, from whom Smith learned much. $W N$ digests French economics but adds much that is new: systematic price theory in Book I and a sophisticated macrodynamics in Book II-somewhat in the manner of present-day introductory textbooks.

Smith's successors in the English School took $W N$ as their analytical starting point. All accepted the standard eighteenth-century macroeconomic conceptions of the surplus (for example, $W N$, IV.ix.27-38), of ecological population growth ( $W N$, I.viii.39-40), and of the dynamic character of economic analysis that follows from these (Waterman 2014a). But in his polemic against Godwin, Malthus combined population growth with the assumption of land scarcity, which has no analytical function in $W N$ and is largely ignored. Thus was born the new concept of 'diminishing returns' to a variable factor when applied to a fixed factor. Scarcity entered the picture formally for the first time, the 'marginal' analysis was born; and Political Economy, the science of wealth, began its gradual, century-long mutation into Economics, the science of scarcity. Smith's own conception of 'increasing returns to scale' arising from the division of 
labour, which operates to alleviate scarcity, was virtually ignored by all his successors save Marx (Waterman 2008).

The self-regulating economy assumed by Smith and the English School depends upon product and factor prices to ration and allocate scarce resources. Smith's own labour theory of price ( $W N$, I.vi) developed by Ricardo and Marx turned out to be a blind alley (Jevons 1879, 72; Samuelson 1957). But his supply-and-demand analysis (WN, I.vii), adopted and improved by Malthus (1800), eventually "won out" (Schumpeter 1954, 482), and was canonised by Marshall (1890). The Demand Curve implies marginal utility, recognised by Condillac in 1776 but ignored until the 1870s. Malthus's theory of 'Ricardian rent' rested on diminishing returns to a joint "labor-cum-capital" variable factor (Samuelson 1978), which implies marginal product. By the end of the nineteenth century marginal product was generalised to all factors, constant returns to scale were assumed, and the 'classical' concept of the surplus was eliminated. Marshall's famous textbook (1890), which grudgingly recognised the work of Jevons and paid tribute to Cournot and Thünen, defined the 'shape' of modern economics for half a century. Radically new theoretical work by Wicksell, Tinbergen, Hicks, Keynes, Harrod and others was not fully digested by 1945. What completed 'the shaping' of present-day economics was the Harvard doctoral thesis of Paul Samuelson (1947).

Adam Smith, Hume and all their successors insisted that politicaleconomy/economics is a 'science'. But what can this mean? By the 1930s philosophers of science had arrived at some form or other of 'operationalism' as a criterion of scientific method Samuelson defined operationally meaningful theorems in his thesis as "hypotheses about empirical data that could conceivably be refuted" (Backhouse 2017, 199-216, 275-276). In supply-and-demand analysis, for example, we can only predict that price will rise if demand increases (a refutable hypothesis), if market equilibrium may exist, if supply and demand curves have the proper slopes, and if a new equilibrium will appear after the demand increase. We must therefore study the existence, uniqueness and stability of equilibrium, and we must do so for a complete set of interdependent markets. Since stability of equilibrium is necessary for prediction, we can deduce from the stability conditions the restrictions which must be placed on the partial derivatives of the behavioural functions, and these must be consistent with our fundamental assumption: that rational individuals act to maximise certain target variables chosen by themselves, subject to constraints imposed by scarcity. ('Rationality' in this case means little more 
than transitivity of the preference set.) Samuelson's thesis became The Foundations of Economic Analysis (1947), which also included a brief treatment of the new 'macroeconomics' of Keynes, and a formal development of the macrodynamic 'period analysis' of the Stockholm School.

But despite his seemingly radical novelty, Samuelson-like Marshall and Adam Smith before him - was deeply conscious of continuity with the political-economy/economics enterprise, and of his own work as summing up and building upon the achievements of his predecessors. In Foundations he cited or referenced the work of nearly forty of his more famous forerunners over the previous two centuries, ranging from Barone, Bastiat, Bentham, Böhm-Bawerk, Bortkiewicz . . . to Adam Smith, Thünen, Veblen, Viner, Walras, Wicksell, and Allyn Young; and including such relatively unexpected authors as Engels, Paley, and Sidgwick. And he was later to say that "within every classical economist there is to be discerned a modern economist trying to be born" $(1978,598)$.

Economics has not stood still in the seventy-two years since Foundations. Its method has been enriched by game theory, linear and dynamic programming, input-output analysis, dynamic optimisation, public choice theory, rational expectations, and information theory. Its scientific pretensions have been maintained by ever more sophisticated econometric methods for testing refutable hypotheses, also by experimental economics and behavioural economics. And its scope has been enlarged by economics of sport, of education, of religion, of the family, of education, and of many more, including even the economics of sin (Cameron 2002). But its 'shape' is still recognisably Samuelsonian: the mathematical formulation and econometric testing of meaningful theorems, formulated on the assumptions of methodological individualism: self-interest and rationality.

Economics is indeed 'sterile' (cf. 2): as a laboratory is and must be sterile. It is not intended to forecast the 2008 crisis or anything else. Its predictions are always subject to ceteris paribus. Like all science, it is, in Karl Popper's words, tentative, provisional, fallible and corrigible.

\section{CONCLUSION}

What's the bottom line? Verburg was betrayed by his own misleading title, for which his publishers and their editors must take some of the blame. There is a lot about 'greed' and 'self-interest' in this publication, much of it of interest to intellectual historians. But very little of it has any bearing 
on 'the shaping of economics' as that term has been understood for more than a century.

\section{REFERENCES}

Backhouse, Roger E. 2017. Founder of Modern Economics: Paul A. Samuelson. Volume I: Becoming Samuelson, 1915-1948. New York, NY: Oxford University Press.

Boisguilbert, Pierre. (1695) 1966. "Le détail de la France: La cause de la diminution de ses biens [. . .]." In Pierre de Boisguilbert ou la naissance de l'économie politique, edited by Jacqueline Hecht, 581-662, 2 vols. Paris: Institut National d'Etudes Démographiques.

Butler, Joseph. (1726) 1969. Fifteen Sermons Preached at the Rolls Chapel and a Dissertation upon the Nature of Virtue. Reprint, edited by Walter Robert Matthews. London: Bell.

Cameron, Samuel. 2002. The Economics of Sin: Rational Choice or No Choice at All? Cheltenham, UK and Northampton, MA: Edward Elgar.

Faccarello, Gilbert. 1999. The Foundations of "Laissez-faire": The Economics of Pierre de Boisguilbert. London: Routledge.

Hamowy, Ronald. 1987. The Scottish Enlightenment and the Theory of Spontaneous Order. Carbondale, IL: Southern Illinois University Press.

Hollander, Samuel. 2008. The Economics of Karl Marx: Analysis and Application. Cambridge: Cambridge University Press.

Hume, David. (1739-1740) 1888. A Treatise of Human Nature. 2 vols. Reprint, edited by Lewis Amherst Selby-Bigge. Oxford: Clarendon.

Hume, David. (1752) 1994. "Of Refinement in the Arts.” In Hume: Political Essays, edited by Knud Haakonssen, 105-114. Cambridge: Cambridge University Press.

Jevons, William S. 1879. The Theory of Political Economy. 2nd edition. London: Macmillan.

Kennedy, Gavin. 2013. “Adam Smith on Religion.” In The Oxford Handbook of Adam Smith, edited by Christopher J. Berry, Maria Pia Paganelli, and Craig Smith, 464-484. Oxford: Oxford University Press.

Levy, David M., and Sandra J. Peart. 2013. "Adam Smith and the State: Language and Reform." In The Oxford Handbook of Adam Smith, edited by Christopher J. Berry, Maria Pia Paganelli, and Craig Smith, 372-392. Oxford: Oxford University Press.

Lessnoff, Michael H. 1994. The Spirit of Capitalism and the Protestant Ethic: An Enquiry into the Weber Thesis. Aldershot: Elgar.

Malthus, Thomas R. 1800. An Investigation of the Cause of the Present High Price of Provisions. By the Author of the Essay on the Principle of Population. London: Johnson.

Marshall, Alfred. 1890. The Principles of Economics. London: Macmillan.

Montchrétien, Antoine de. (1615) 1889. Traité de l'économie politique. Reprint, edited by Théophile Funck-Brentano. Paris: Plon.

Samuelson, Paul A. 1947. Foundations of Economic Analysis. Cambridge, MA: Harvard University Press.

Samuelson, Paul A. 1957. "Wages and Interest: A Modern Dissection of Marxian Economic Models." American Economic Review 47 (6): 884-912.

Samuelson, Paul A. 1978. "The Canonical Classical Model of Political Economy.” Journal of Economic Literature 16 (4): 1415-1434. 
Schumpeter, Joseph A. 1954. History of Economic Analysis. London: Allen \& Unwin.

Shaftesbury, Anthony Ashley Cooper, the Earl of. 1711. Characteristicks of Men, Manners, Opinions, Times. London: Publisher Unknown.

Smith, Adam. (1776) 1976. An Inquiry into the Nature and Causes of the Wealth of Nations. 2 vols. Oxford: Oxford University Press. Exact photographic reproduction, 1981. Indianapolis, IN: Liberty Fund.

Smith, Adam. (1759, 1790) 1976. The Theory of Moral Sentiments. 6th edition. Edited by Alec L. Macfie, and David D. Raphael. Oxford: Oxford University Press.

Tucker, Josiah. (1755) 1993. The Elements of Commerce and Theory of Taxes. Vol. 3 of The Collected Works of Josiah Tucker. London: Routledge/Thoemmes.

Waterman, Anthony M. C. 2008. "English School of Political Economy." In Vol. 2 of The New Palgrave Dictionary of Economics, edited by Steven N. Durlauf, and Lawrence E. Blume, 858-868. 2nd edition. London: Palgrave Macmillan.

Waterman, Anthony M. C. 2014a. "Is There Another, Quite Different, 'Adam Smith Problem?'” Journal of the History of Economic Thought 36 (4): 401-420.

Waterman, Anthony M. C. 2014b. "Theology and the Rise of Political Economy in Britain in the Eighteenth and Nineteenth Centuries." In The Oxford Handbook of Christianity and Economics, edited by Paul Oslington, 94-112. Oxford: Oxford University Press.

Waterman, Anthony M. C. 2015. "Moral Philosophy or Economic Analysis? The Oxford Handbook of Adam Smith.” Review of Political Economy 27 (2): 218-229.

A. M. C. Waterman is a Fellow of St John's College Winnipeg and Professor of Economics at the University of Manitoba. Since 1980 his research has addressed the relation between economic theory and Christian theology, in particular its intellectual history. His Revolution, Economics and Religion (Cambridge, 1991) won the Forkosch Prize for Intellectual History in 1992. In 2007 he was made Distinguished Fellow of the History of Economics Society and in 2014 an Honorary Member of the European Society for the History of Economic Thought.

Contact e-mail: <Anthony.Waterman@umanitoba.ca>

Website: <amcwaterman.com> 